\title{
PENGGUNAAN SIMBOL PADA PROSES INTERAKSI SIMBOLIK SISWA TUNAGRAHITA DAN GURU DI SEKOLAH LUAR BIASA
}

\section{USE OF SYMBOLS IN SYMBOLIC INTERACTION PROCESSES OF INTELLECTUAL DISABILITIES STUDENT AND TEACHER IN SPECIAL SCHOOL}

\author{
Khafi Maulana Rahman ${ }^{1 *}$, Agustina M. Purnomo², Agustini $^{3}$ \\ ${ }^{123}$ Program Studi Sains Komunikasi, Fakultas Ilmu Sosial dan Ilmu Politik, Universitas DjuandaBogor, \\ Jl. Tol Ciawi No.1 Kotak Pos 35 Bogor 16720 \\ *Korespondensi: Khafi Maulana Rahman, Email: Khafim18@gmail.com
}

(Diterima oleh Dewan Redaksi: 20 Juni 2020)

(Dipublikasikan oleh Dewan Redaksi: 5 Oktober 2020 )

\begin{abstract}
Symbolic interaction between students and teachers as a process of action and reaction involving an exchange of symbols. The symbols are formed and exchanged at the same time as the use of symbols in three levels, namely mind, self and society in symbolic interaction between mentally disabled students and teachers in special schools. The purpose of this study was to determine the use of mental retardation students and teachers in Special Schools. Descriptive qualitative research methods to explain phenomena accurately about existing facts. Data collection techniques through observation and in-depth interviews. Tunagrahita Teachers and Students in Special Schools become key informants in research, parents and closest friends become supporting informants. Data analysis technique is done by presenting data from Creswell. The theoretical foundation used in the research of Symbolic Interactionism from Mead. The results showed that the use of symbols in the mind, self and society level had an important role in the process of using symbols (manipulation and consumption) in the process of symbolic interaction. The conclusion of the research is the process of using symbols influenced by three levels of symbolic interaction, namely mind, self and society. Symbolic interaction at the level of society shows different levels according to the social and cultural background of students. Agreements that are built through symbolic interactions between teachers and students help students understand and understand social structures at school and at home, so they can constrain how they act and behave to suit other individuals.
\end{abstract}

Keywords: symbolic interaction; teachers, use of symbol 


\begin{abstract}
ABSTRAK
Interaksi simbolik antara siswa dan guru sebagai proses aksi dan reaksi yang melibatkan sebuah pertukaran simbol. Simbol-simbol tersebut dibentuk dan dipertukarkan dalam saat yang bersamaan dengan penggunaan simbol dalam tiga tataran yaitu mind, self dan society dalam interaksi simbolik antara siswa tunagrahita dan guru di sekolah luar biasa. Tujuan penelitian untuk mengetahui penggunaan simbol siswa tunagrahita dan guru di Sekolah Luar Biasa. Metode penelitian deskriptif kualitatif untuk menjelaskan fenomena secara akurat tentang fakta-fakta yang ada. Teknik pengumpulan data melalui observasi dan wawancara mendalam. Guru dan Siswa Tunagrahita di Sekolah Luar Biasa menjadi informan kunci dalam penelitian, orang tua dan teman terdekat menjadi informan pendukung. Teknik analisis data dilakukan dengan penyajian data dari Creswell. Landasan teori yang digunakan dalam penelitian Interaksionisme Simbolik dari Mead. Hasil penelitian menunjukkan bahwa penggunaan simbol ditataran mind, self dan society memiliki peran penting dalam proses penggunaan simbol (manipulasi dan konsumsi) dalam proses interaksi simbolik. Kesimpulan penelitian adalah proses penggunaan simbol dipengaruhi tiga tataran interaksi simbolik yaitu mind, self dan society. Interaksi simbolik di tataran society menunjukan level yang berbeda sesuai dengan latar belakang sosial dan budaya dari siswa. Kesepakatan yang dibangun melalui interaksi simbolik antara guru dengan siswa membantu siswa mengerti dan paham struktur sosial di sekolah maupun di rumah, sehingga mereka dapat membendakan bagaimana mereka bertindak dan berperilaku agar sesuai dengan individu lain.
\end{abstract}

Keywords: guru, interaksi simbolik, penggunaan simbol

Khafi Maulana Rahman, Agustina M. Purnomo, Agustini. 2020. Penggunaan Simbol pada Proses Interaksi Simbolik Siswa Tunagrahita dan Guru di Sekolah Luar Biasa. Jurnal Komunikati 6 (2): 77-92. 


\section{PENDAHULUAN}

Interaksi simbolik antara guru dan siswa tunagrahita terjadi dalam proses pendidikan. Interaksi simbolik itu sendiri untuk memahami proses komunikasi di dalam kegiatan belajar mengajar dan di luar kegiatan belajar mengajar. Siswa tunagrahita memiliki keunikan tersendiri yang mungkin berbeda dengan siswa biasa. Tunagrahita adalah suatu kondisi anak yang kecerdasannya jauh dibawah rata-rata dan ditandai oleh keterbatasan intelegensi dan ketidakcakapan dalam komunikasi sosial. Anak berkebutuhan khusus ini juga sering dikenal dengan istilah terbelakang mental karena keterbatasan kecerdasannya. Akibatnya anak berkebutuhan khusus tunagrahita ini sukar untuk mengikuti pendidikan disekolah biasa (Atmaja, 2018).

Interaksi simbolik pada sisi faktualnya bahwa manusia menggunakan simbol, mengukir dan bertindak terhadap objek daripada hanya menanggapi rangsangan. Menurut Mead (dalam Ritzer \& Douglas, 2010) simbol atau tanda yang diberikan oleh manusia dalam melakukan interaksi mempunyai makna-makna tertentu sehingga dapat menimbulkan komunikasi. Komunikasi secara murni baru terjadi bila masing-masing pihak tidak saja memberikan makna pada perilaku mereka sendiri, tetapi memahami atau berusaha memahami makna yang diberikan oleh pihak lain.

Interaksi

simbolik

sangat

memfokuskan pada ide-ide dasar dalam membentuk makna yang berasal dari pikiran manusia (mind), mengenai diri (self) dan hubunganya di tengah masyarakat (society), (Hewitt dalam Elbadiansyah, 2014). Interaksi simbolik memiliki peran penting dalam memahami secara detail interaksi sosial untuk menafsirkan berbagai fenomena yang muncul. Dalam proses interaksi sosial muncul karena adanya pikiran (mind) pada diri (self) individu dalam realitas sosial (society). Ketiga ide dasar dari interaksi simbolik dapat melihat secara dinamis terkait makna dari tindakan sosial.

Menurut Mead (dalam Elbadiansyah, 2014) ada empat tahapan tindakan dalam proses interaksi simbolik yaitu tahap dukungan dari luar diri individu, tahap persepi yaitu saat individu menyeleksi situasi di sekitarnya, tahap manipulasi merupakan tahap yang dibentuk dalam pertanyaan "apa yang harus saya perbuat atau lakukan?" dan tahap konsumsi yaitu proses pengambilan tindakan sesuai dengan peran dimainkan oleh individu.

Peneliti memfokuskan penelitian ini pada proses penggunaan simbol dalam interaksi simbolik yang terjadi antara siswa berkebutuhan khusus tunagrahita dengan guru. Maka tujuan penelitian ini untuk mengetahui penggunaan simbol siswa tunagrahita dan guru di Sekolah Luar Biasa, agar interaksi simbolik antara guru dan siswa tunagrahita pada proses komunikasi simbolik yang mungkin berbeda dengan siswa biasa dapat dipahami. 
MATERI DAN METODE PENELITIAN

\section{MATERI}

\section{Interaksi Simbolik}

Interaksi simbolik antara siswa tunagrahita dan guru tidak hanya melihat pertukaran pesan antara keduanya, tetapi sebagai proses aksi dan reaksi yang melibatkan sebuah pertukaran simbol antara siswa dan guru di dalam kelas maupun di luar kelas. Ide-ide dasar dalam membentuk makna dari simbol berasal dari pikiran manusia (mind), konsep diri (self) dan hubungan ditengah masyarakat (society). Simbol-simbol tersebut dibentuk dan digunakan dalam waktu yang bersamaan.

Tahap pembentukan dan penggunaan simbol melalui empat tahapan yaitu dorongan dan persepsi sebagai tahap pembentukan simbol. Tahap manipulasi dan konsumsi sebagai tahap penggunaan simbol. Keempat tahapan tindakan ini yang mendasari kesadaran diri individu sebagai pijakan dalam berinteraksi sosial.

Tahap dorongan menjadi tahap awal pembentukan simbol dari luar diri anak tunagrahita yaitu orang lain dan lingkungan sekitar yaitu dari guru, orang tua dan teman yang ditangkap oleh alat indera. Kemudian anak tunagrahita menganggapi dorongan tersebut sebagai sebuah reaksi dan tindakan, anak tunagrahita akan berfikir dan mempertimbangkan situasi saat ini, masa lalu untuk mengantisipasi masa depan. Tahap persepsi menjadi tahap kedua dalam proses pembentukan simbol dimana anak tunagrahita akan bereaksi terhadap dorongan yang didapat dari orang disekitarnya lalu menanggapi dengan membentuk persepsi terhadap keadaan dan tindakan dari orang disekitarnya. Tahap ketiga, tahap manipulasi sebagai tahap tindakan penggunaan simbol yaitu tahap pengambilan dan berfikir tindakan agar tanggapan yang diwujudkan tidak secara spontan. Tahap terakhir tahap konsumsi tahap ini anak-anak tunagrahita mulai aktif mengambil peran dilingkungan sekitar bersama orang-orang disekitanya. Pada kerangka ini Mead menyadari bahwa individu akan terlibat aktifitas yang di dalamnya akan mempengaruhi perilaku. Maka penelitian ini akan melihat proses pembentukan dan penggunaan simbol siswa tunagrahita dalam tiga tataran yaitu mind, self, dan society (Mead dalam Elbadiansyah, 2014).

\section{Kerangka Berpikir}

Interaksi antara siswa tunagrahita dan guru dimulai saat guru memberikan stimulus kepada siswa untuk menyampaikan pesanpesan melalui pembentukan simbol-simbol secara verbal maupun non verbal yang selanjutnya proses memahami dan menfasirkan pesan oleh siswa sebelum akhirnya memberikan respons.

Guru memberikan stimulus untuk memperkuat pesan melalui media-media pengajaran tertentu dan respon dari siswa atas stimulus yang diberikan guru didalam proses belajar mengajar. Pemahaman siswa terhadap pesan-pesan serta media yang 
digunakan saat proses belajar merupakan sebuah proses pembentukan simbol. Pembentukan simbol tersebut lahir dari hasil pemahaman siswa dari stimulus yang diberikan guru serta dipengaruhi juga oleh lingkungan keluarga dan orang terdekatnya.

Interaksi simbolik adalah sebuah proses dimana tidak hanya memandang pesan sebagai stimulus atau respon semata, tetapi sebagai aksi dan reaksi atau pertukaran simbol antara guru dan siswa tunagrahita. Interaksi simbolik antara siswa tunagrahita dan guru tidak hanya melihat pertukaran pesan antara keduanya, tetapi sebagai proses aksi dan reaksi yang melibatkan sebuah pertukaran simbol antara siswa dan guru. Simbol-simbol tersebut dibentuk dan dipertukarkan dalam saat yang bersamaan.

Siswa tunagrahita akan menggunakan simbol ulang dari apa yang dia peroleh dari gurunya dan dari rumahnya untuk menanggapi dan merespon apa yang diberikan oleh gurunya tersebut dalam proses belajar sehingga proses tersebut terjadi secara timbal balik. Selanjutnya penggunaan simbol yang dibentuk siswa kepada gurunya tersebut akan menggunakan simbol yang berarti sama dengan apa yang guru sampaikan. Penggunaan simbol siswa tunagrahita diperoleh dari rumah dan dari sekolah untuk berinteraksi dengan gurunya.

Penggunaan simbol yan telah dibentuk melalui dua tahapan menurut Mead (dalam Elbadiansyah, 2014) yaitu tahap manipulasi dengan cara memikirkan apa yang akan dilakukan dengan simbol yang telah dibuat dan bagaimana akan menggunakan simbol tesebut. Sedangkan tahap konsumsi, dimana siswa dan guru langsung menggunakan simbol tersebut pada proses interaksi simbolik pada level mind, self dan society.

Penggunaan simbol pada proses interaksi simbolik siswa tunagrahita dan guru di sekolah luar biasa dilihat pada bagan sebagai berikut: 


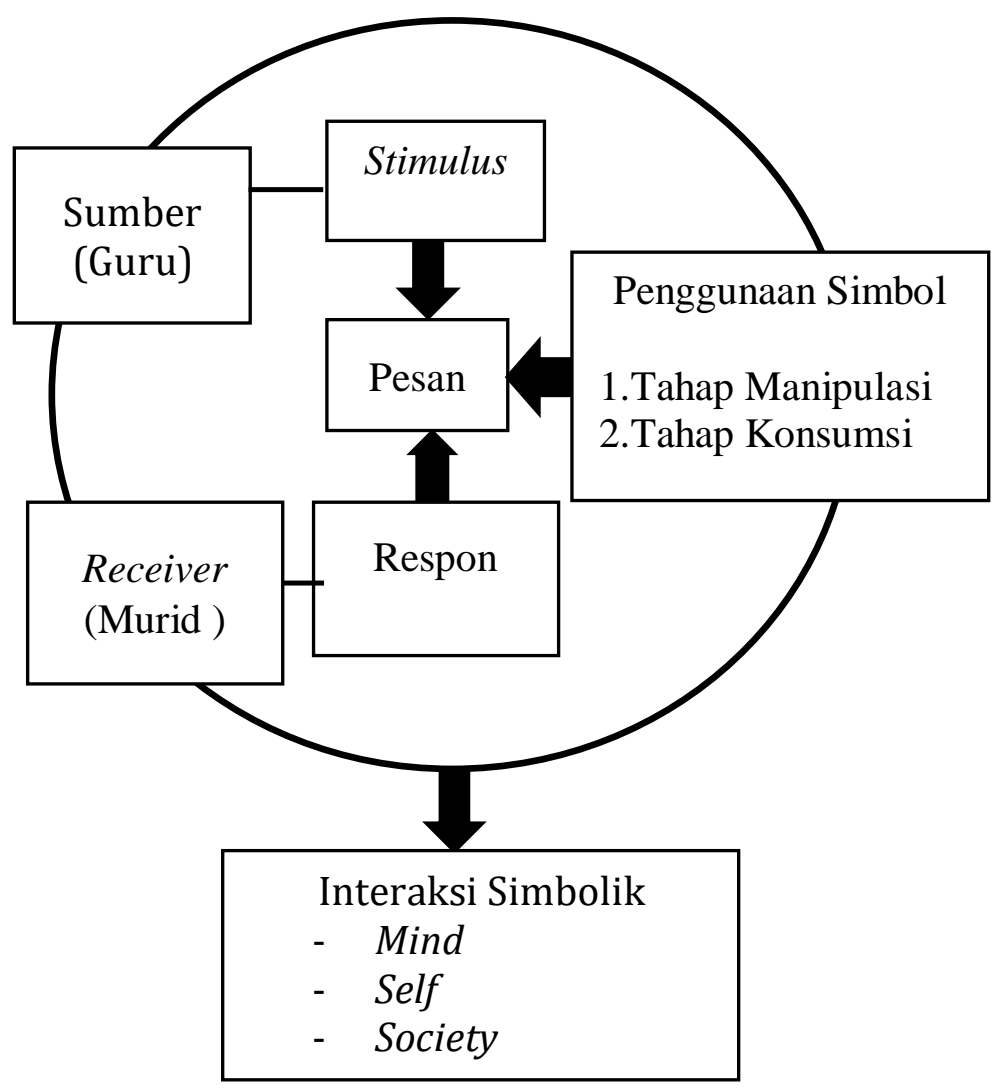

Gambar 1. Kerangka Berpikir Peggunaan Simbol Pada Proses Interaksi Simbolik Siswa Tunagrahita dan Guru Di Sekolah Luar Biasa

\section{METODE PENELITIAN}

Metode penelitian yang digunakan deskriptif kualitatif. Penelitian kualitatif bermaksud untuk memahami fenomena mengenai suatu hal yang dialami subjek penelitian seperti persepsi, perilaku, motivasi, tindakan dan lain sebagainya, secara holistik dideskripsikan dalam bentuk kata-kata juga bahasa (Moleong, 2016). Sedangkan deskriptif kualitatif berfokus pada subyek dan obyek penelitian serta mencari fakta melalui penginterpretasian yang tepat (Nazir, 2014).
Teknik pengumpulan data dilakukan dalam kondisi alamiah, sumber data primer diperoleh langsung dari sumber utama melalui informan kunci dan informan pendukung. Sumber data sekunder diperoleh dari data yang sudah ada dalam bentuk dokumentasi, data-data untuk memperkuat data primer (Sugiyono, 2016).

Adapun sumber data primer pada penelitian diperoleh melalui observasi kegiatan belajar mengajar disekolah luar biasa, proses interaksi siswa tunagrahita dengan orang-orang disekitarnya dan melalui wawancara mendalam untuk 
memperoleh informasi secara langsung dan mendalam dari informan. Guru tunagrahita dan siswa tunagrahita sebagai informan kunci, orang tua siswa dan teman terdekat sebagai informan pendukung. Data sekunder diperoleh dari dokumentasi, buku-buku serta laporan dari sekolah luar biasa.

Teknik analisis data adalah proses mencari dan menyusun secara sistematis data yang diperoleh dari hasil wawancara, catatan lapangan dan dokumentasi dengan cara mengorganisasikan data ke kategori, menjabarkan ke dalam unit-unit, memilih yang penting hingga membuat kesimpulan (Sugiyono, 2016).

Dalam prosesnya, penelitian ini menganalisis data dengan teknik analisis penyajian Creswell (2013) melalui tahapan analisis yaitu menyiapkan data yang akan dianalisis melibatkan transkip wawancara memilah data dan menyusun data tersebut. Tahap reduksi data dengan cara coding dan meringkas kode, serta penyajian data berupa bagan, tabel dan pembahasan, merefleksikan maknanya secara keseluruhan. Menganalis lebih detail dengan coding, mengolah materi dan data menjadi segmen tulisan sebelum memaknainya. Menerapkan proses coding untuk mendeskripsikan semua informasi. Penyajian deskripsi dalam bentuk narasi/laporan kualitatif. Langkah terakhir menginterpretasi atau memaknai data, interpretasi bisa berupa makna perbandingan antara hasil penelitian dengan informasi dari literatur atau teori (Creswell, 2013).

\section{HASIL DAN PEMBAHASAN}

\section{A. Proses Interaksi Simbolik Siswa Tunagrahita dan Guru (Mind, Self, Society)}

Wawancara dengan tiga informan kunci dan empat informan pendukung, proses pembentukan dan penggunaan simbol dalam proses interaksi simbolik antara siswa tunagrahita dan guru di sekolah luar biasa dilihat melalui 3 tataran yaitu tataran mind, self dan society.

\section{Mind}

Menurut Mead pada tataran mind, ide-ide dasar dalam membentuk makna dari simbol berasal dari pikiran manusia. Pada tataran ini, manusia bertindak terhadap manusia lainnya berdasarkan makna yang diberikan orang lain kepada mereka (Elbadiansyah, 2014). Tataran ini dapat diamati dari proses pembentukan simbol "pujian” di Guru. Guru berpikir bahwa murid (Ririn dan Ega) memerlukan pujian agar lebih semangat belajar. Pikiran ini membentuk proses di dalam tataran mind Guru dan menyebabkan Guru membangun simbol-simbol pujian untuk Ririn dan Ega. Ini ditunjukkan oleh pendapat Guru:

"Ibu pasti memberikan pujian karena kan mereka sangat butuh dukungan dan reward dari kita, agar 
mau dan semangat belajar. Salah satunya itu memberi pujian dan perhatian kepada mereka berdua. Selesai belajar menulis atau menggambar pasti ibu beri pujian, seperti bilang pintar atau rajin kepada mereka, biar mereka lebih semangat belajar. Biasanya mereka cuman senyum dan mengangguk kalau dipuji. Ririn biasanya pasang wajah malu-malu. Ega saat dipuji biasanya dia minta tugas lagi. Kaya tadi kan dia lagi mewarnai, ibu puji 'Ega pinter ih hebat!' dia langsung minta lagi tugas langsung semangat, padahal sudah waktunya pulang." (Ibu Tina, 5 Desember 2019).

Ririn, Ega dan Ibu Tina bertindak sesuai dengan makna yang diberikan atau diterima oleh mereka. Stimulus berupa pujian tersebut direspon secara sama oleh $\mathrm{E}$ dan $\mathrm{R}$ dengan beberapa tanda, simbol, dan gerakan yang menunjukkan arti yang sama dan sesuai makna. Berdasarkan pengamatan, Ririn menunjukkan simbol senang terhadap pujian dengan tersenyum malu dan menunjukkan respon positif melalui tindakan dengan mengerjakan tugasnya setelah diberi pujian. Pujian direspon oleh Ega dengan simbol senyum dan wajah bersemangat dan tindakan Ega meminta tugas untuk dikerjakan.

Selanjutnya Mead mengatakan pada tataran mind, makna dimodifikasi melalui proses interpretif. Makna pujian yang dibentuk oleh Guru diinterpretasikan oleh Ririn dan Ega saat proses pembelajaran di dalam kelas. Sebaliknya, jika interpretasi makna pujian yang diberikan oleh Ririn dan Ega sama dengan interpretasi Guru dalam memberikan pujian, Guru akan merespon balik. Sebagai contoh, perhatian penuh dan pelukan yang diinterpretasi sebagai pujian atau dukungan oleh Guru terhadap Ega dan Ririn dianggap mampu membantu Ega dan Ririn lebih semangat dalam mengikuti pembelajaran maka Guru akan melakukannya kembali.

\begin{abstract}
"Ibu kalau mengajar anak kaya Ririn harus selalu men-support dan kasih reward untuk dia. Harus selalu dikasih perhatian penuh sama dia. Kadangkadang kalau dia udah marah dan kurang perhatian dari guru gitu mereka tidak mau mengikuti pelajaran, makanya mereka harus selalu dapat reward. Kaya tadi pagi kan, 'Bu! Bu!' Ibu kan diam aja dipanggil, langsung marah kan dia. Makanya begitu mereka datang mereka harus langsung dipeluk, dielusin. Perhatian tuh harus pehatian penuh sama dia gitu, ga boleh ke orang lain." (Ibu Tina, 5 Desember 2019).
\end{abstract}

Mead menjelaskan, makna diciptakan dalam interaksi antar manusia. Pada kasus interaksi simbolik antara Ibu Tina, Ega dan Ririn, konsep Mead ini ditunjukkan melalui interaksi di dalam kelas dan di luar kelas seperti saat jam-jam istirahat dan bahkan saat di rumah. Interaksi yang diciptakan oleh ketiganya sangat dalam sehingga dapat menciptakan makna yang baik antara Ibu Tina, Ega dan Ririn. Interaksi di dalam dan 
di luar kelas dianggap penting oleh Ibu Tina karena menurut pengalaman Ibu Tina kedalaman interaksi yang telah dijalin antara ketiganya dapat menciptakan makna yang baik mengurangi kesalah pahaman antar individu, makna yang diberikan dan makna yang akan diterima akan sama dan selaras, sehingga proses belajar mengajar didalam kelas pun berjalan efektif. Hal ini juga dipikirkan sama oleh Ega dan Ririn. Ega dan Ririn menjelaskan sikap dari Ibu Tina.

"Ririn tuh ga pernah betah kalau belajar di dalam kelas harus di luar terus. Makanya belajarnya dimana aja yang penting dia nyaman jadi kita mengikuti keinginan dia. Harusnya kan di kelas tapi karena Ririn betah di luar kaya tadi di atas tangga kita ikutin, seharusnya di sebelah ruangan Ibu Memi. Kalau di kelas dia ga mau belajar jadi lebih baik di luar agar dia mau mengikuti gitu, yang penting dia mau ikut belajar jadi kita ga memaksa buat di kelas. Jadi ibu menyesuaikan dengan keinginan anaklah, anak maunya dimana enaknya (Ibu Tina, 12 Desember 2019)."

“Baik pisan, sayang Ririn! peluk Ririn! Ega: Mengangguk, tertawa, memberikan jempol" (Ega dan Ririn, 12 Desember 2019).

Ini menunjukkan pendapat Mead bahwa Individu mengembangkan pikiran mereka melalui interaksi dengan individu lain terbukti dalam kasus Ibu Tina, Ega dan Ririn.
Pada tataran Mind, Mead mengatakan makna dibentuk oleh kesepakatan bersama. Pada kasus interaksi antara Ibu Tina, Ega dan Ririn, ini dapat diamati saat Ibu Tina bercanda dengan Ega, lalu Ririn yang kurang suka langsung menunjukan simbol tidak suka dengan raut wajah cemberut sambil membalikan badan dan terdiam. Ibu Tina menyepakati makna ketidak-sukaan Ega dan memahami simbol ketidak-sukaan tersebut harus direspon dengan simbol dukungan (pelukan dan kata-kata menenangkan), dan Ibu Tina memahami untuk mengajak Ega dalam menunjukkan simbol dukungan ini (meminta Ega menghibur Ririn), Ririn dapat kembali tenang dan ceria.

Proses kesamaan makna yang mendukung keberhasilan interaksi antara Guru, Ririn dan Ega ini terbangun melalui interaksi yang dalam dan adanya kepekaan dan rasa tanggap dari Ibu Tina terhadap Ega dan Ririn. Kasus interaksi antara Ibu Tina, Ega dan Ririn menunjukkan kesamaan makna terhadap simbol yang dibangun dan digunakan dalam interaksi antara Ibu Tina, Ega dan Ririn. Ini ditunjukkan dengan adanya hubungan baik dan mendalam antara Ibu Tina, Ega dan Ririn.

Mead juga menyatakan kemampuan seseorang dalam menggunakan simbol yang bermakna sosial sama dalam konsep Mind. Di dalam kasus Ibu Tina, Ega dan Ririn ditunjukkan dengan pemberian stimulus oleh Ibu Tina berupa perhatian lebih kepada Ega dan Ririn ketika mereka belum 
siap untuk memulai pelajaran di dalam kelas. Ini menunjukkan bahwa Ibu Tina mampu menggunakan simbol yang bermakna sosial sama. Biasanya saat mereka datang Ibu Tina langsung memberikan pelukan hangat agar mereka semangat dalam pembelajaran. Ega dan Ririn pun mampu memberikan simbol yang bermakna sosial sama ketika mereka menunjukan perasaan mereka di dalam kelas ketika belum siap untuk mengikuti proses belajar mengajar. Mereka menunjukan beberapa tanda, gerakan dan simbol yang menunjukan bahwa mereka sedang mengungkapkan perasaan mereka dan berharap mendapatkan respon yang baik atau sama dari Ibu Tina. Saat Ririn belum siap mengikuti proses pembelajaran biasanya Ririn menjatuhkan diri di lantai atau tiduran di lantai. Guru meminta bantuan Ega untuk memberi semangat Ririn untuk mengikuti pembelajaran.

\section{Self}

Self merupakan konsep Mead yang merupakan pengembangan konsep diri melalui individu secara aktif, didasarkan pada interaksi sosial dengan orang lainnya. Pemikirian Mead ditunjukkan kemampuan Ega dan Ririn untuk mengembangkan diri dari waktu ke waktu secara aktif umumnya di lingkungan sekolah dan khususnya di dalam kelas saat proses pembelajaran (Elbadiansyah, 2014).

Pengembangan konsep diri Ega dan Ririn dipengaruhi oleh interaksi antara keduanya di dalam kelas dengan Guru. Ririn menunjukkan pengembangan diri saat belajar karena adanya sosok sahabat baiknya yaitu Ega dan Ibu Tina yang selalu memberikan dukungan penuh saat proses belajar di dalam kelas serta dukungan dari kedua orang tuanya saat berada di luar lingkungan sekolah. Ririn dan Ega terbukti mengembangkan konsep diri secara aktif, didasarkan pada interaksi sosial dengan orang lainnya.

Konsep self juga menyatakan bahwa konsep diri membentuk motif yang penting untuk berperilaku. Pemikiran Mead ini sejalan dengan apa yang dilakukan oleh Ibu Tina, Ega dan Ririn di dalam proses belajar. Konsep diri dari dalam diri mereka menciptakan motif yang sangat penting dalam berperilaku dan bertindak khususnya dalam proses pembelajaran. Konsep diri Ibu Tina dalam mengajar anak tunagrahita Lillahi Ta'ala mendorong motif mengajar anak-anak tunagrahita dengan motivasi mengajar untuk ibadah. Motif ini menjadikan Ibu Tina betul-betul berusaha memahami Ega dan Ririn, melakukan mengajar dengan sepenuh hati dan paham bagaimana untuk mengajar siswa seperti Ega dan Ririn yang memiliki motif belajarnya masing-masing.

Konsep self dari Mead mengatakan bahwa setiap individu membayangkan dan mengimajinasikan perilaku dan kepribadian akan dilihat orang lain. Sikap dan perilaku Guru akan dinilai oleh Ega dan Ririn saat mengajar dan sebaliknya juga 
Guru akan menilai sikap dan perilaku E dan $\mathrm{R}$ saat belajar di dalam kelas. Ibu Tina bisa membayangkan tindakan atau sikap apa yang harus diambil ketika menghadapi sesuatu dalam proses belajar agar dapat dibayangkan sesuai dengan image yang ingin dibangun di benak Ega dan Ririn. Sebagai contoh, Ibu Tina yang memberikan pelukan dan elusan yang agar dapat dibayangkan sebagai sosok yang menyayangi dan mengasihi Ega dan Ririn. Simbol ini ditangkap oleh Ega dan Ririn dan membayangkan Ibu Tina sebagai sosok yang sangat perhatian dan penuh dengan kasih sayang kepada mereka. Ini menunjukkan simbol tersebut telah disepakati sebelumnya melalui interaksi yang telah dibangun didalam konsep Mind.

Pemikiran Mead dalam konsep self yang terakhir yaitu mengambil sikap diri untuk situasi sosial yang berbeda. Ega dan Ririn bisa menempatkan diri disituasi dan keadaan berbeda. Mereka dapat menyesuaikan dengan orang-orang baru yang mereka temui. Ibu Tina dapat menempatkan posisi juga untuk memahami anak-anak yang berbeda sikap dan kepribadiaanya. Tindakan ini menunjukan individu mengambil sikap diri untuk situasi sosial atau mempunyai banyak 'diri' untuk kelompok berlainan yang merespon. Pada kasus Ega dan Ririn, Ega lebih berhasil dalam proses ini. Ega merupakan anak yang cukup aktif, mampu menerima kehadiran orang-orang baru disekitarnya, mampu menyesaikan diri dengan lingkungan dan orang-orang yang baru dia temui atau dapat disimpulkan Ega lebih mampu melakukan konsep "memperbanyak diri. Ririn masih terlihat malu-malu ketika bertemu dengan orang-orang baru di sekitarnya. Konsep ini ditunjukkan dengan kemampuan Ibu Tina untuk memilih sikap yang berbeda dalam menghadapi Ega dan Ririn.

\section{Society}

Konsep yang terakhir yaitu Society dikatakan Mead (dalam Elbadiansyah, 2014), orang dan kelompok masyarakat dipengaruhi oleh proses budaya dan sosial. Pada kasus Ibu Tina, Ega dan Ririn ditunjukan pengaru sosial budaya terhadap keunikan Ega dan Ririn. Keunikan Ega dan Ririn disebabkan oleh pengaruh hubungan dengan orang tua, saudara-saudara, temanteman dan guru.

Sikap dan kebiasaanya saat dirumah terbawa ke lingkungan sekolah mulai dari perasaan, cara bersosialisasi maupun cara belajar. Ririn yang pasif bersosialisasi di rumah terlihat pasif ketika bersosialisasi di sekolah. Orang tua dari Ririn mengatakan bahwa Ririn saat di rumah lebih banyak diam di rumah, lebih banyak menonton video-video lucu di handphone dibandingkan bermain di luar bersama teman-teman. Sikap Ririn di sekolah sama dengan di rumah. Ririn hanya dekat dengan sahabat satu kelasnya yaitu Ega. Ririn tidak bisa jauh dari Ega. Pada kasus Ega, Ega merupakan anak yang cukup aktif di rumah, sering bercanda dengan saudara-saudara 
dan ayah. Ini membuat Ega cukup mudah membuka diri terhadap orang-orang baru di sekitarnya. Ega dikenal akrab dengan teman-teman lain di sekolah, senang bermain sepak bola bersama Fajar yang merupakan teman dekat Ega. Hubungan baik Ega saat di rumah mempengaruhi Ega saat di sekolah.

Mead juga menjelaskan tentang stuktur sosial dihasilkan melalui interaksi sosial dalam konsep Society. Pemikiran Mead ini dibuktikan dalam kasus Ibu Tina, Ega dan Ririn dimana mereka membentuk struktur sosial atau kedudukan dan posisi di lingkungan sekolah melalui interaksi antar teman dan guru disekolah. Ega mampu membedakan komunikasi ketika saat bersama Ibu Tina dan Fajar. Ega lebih aktif ketika bermain dengan Fajar di luar kelas, bahasa yang digunakan oleh Ega lebih santai ketika waktu bermain dengan Fajar dibandingkan saat berkomunikasi dengan Ibu Tina. Ini menunjukkan Ega mampu memilih simbol yang tepat saat berinteraksi dengan guru dan bagaimana saat berhubungan atau berinteraksi dengan teman sebaya.

\section{B. Penggunaan Simbol Siswa Tunagrahita Siswa Tunagrahita dan Guru}

Mead mengatakan ada empat tahapan tindakan interaksionisme simbolik dalam proses pembentukan simbol dan penggunaan simbol (dalam Elbadiansyah, 2014). Ibu Tina, Ega dan Ririn melewati 2 tahapan pertama dalam proses pembentukan simbol sebelum digunakan dalam proses interaksi, yaitu tahap dorongan yang ditunjukan dengan pemberian pujian, pelukan serta kasih sayang dari guru kepada Ega dan Ririn. Tahap persepsi muncul setelah adanya dorongan dari Ibu Tina sehingga Ega dan Ririn membentuk persepsi tentang Guru. Dua tahap ini, dorongan dan persepsi merupakan tahapan pembentukan simbol yang selanjutnya digunakan pada dua tahapan berikutnya dalam penggunaan simbol yaitu tahap manipulasi dan konsumsi yang terjadi pada proses interaksi simbolik yaitu:

\section{Tahap Manipulasi}

Tahapan pertama dalam proses penggunaan simbol adalah manipulasi. Setelah tahap dorongan dan persepsi dalam proses pembentukan symbol. Langkah selanjutnya adalah memanipulasi objek atau mengambil tindakan terhadap dorongan dan persepsi. Tahap ini merupakan tahap jeda yang paling penting dalam proses tindakan agar tanggapan tak diwujudkan secara spontan. Tahap ini dibangun dari pertanyaan "apa yang harus diperbuat?" Ega dan Ririn melewati tahap manipulasi setelah menyelesaikan tahap persepsi didalam proses pembentukan dengan melakukan interaksi sosial bersama guru, teman dan orang tuanya. Tahap manipulasi ditunjukkan dengan melakukan tindakan sesuai dengan persepsi yang telah dibentuk kepada individu lain. Misalnya 
bagaimana cara Ega dan Ririn memilih tindakan kepada guru yang sudah mereka anggap sangat baik, atau saat Ega dan Ririn memilih tindakan kepada orang tua dan kepada teman. Ini ditunjukkan saat bersama orang tua Ega dan Ririn memilih simbol yang berbeda dengan saat bersama dengan teman dan guru. Sikap yang ditunjukan Ririn dan Ega hampir sama ketika mereka bersama dengan guru dan orang tua karena pada tahap manipulasi Ega dan Ririn memilih sikap yang sama. Ini menunjukkan Ega dan Ririn menilai Guru dan orang tua sama-sama memberikan support dan perhatian penuh kepada Ega dan Ririn.

\section{Tahap Konsumsi}

Tahap konsumsi merupakan tahap pelaksanaan atau mengambil tindakan yang memuaskan hati yang sebenarnya. Tahap pemenuhan tindakan sesuai dengan peran yang dimainkan oleh diri (Elbadiansyah, 2014). Pada tahap ini Ega dan Ririn mulai aktif dalam mengungkapkan perasaan yang mereka ingin ungkapkan, menyampaikan pesan yang ingin mereka sampaikan kepada orang-orang disekitarnya. Baik melalui pesan verbal maupun pesan nonverbal. Mereka dapat aktif dalam membangun interaksi sosial dengan orang-orang disekitarnya.

Ega dan Ririn mampu mengungkapkan apa yang ingin mereka ungkapkan kepada guru, orang tua atau teman. Mereka telah melewati tahap dorongan yang diberikan oleh guru, orang tua dan teman. Menyelesaikan tahap persepsi dengan menganggap dan menilai guru, orang tua dan temannya adalah orang yang baik. Melewati tahap manipulasi dengan bisa membedakan cara berinteraksi antara guru, orang tua dan teman.

Empat tahap yang dilewati Ega dan Ririn akhirnya membentuk simbol-simbol dalam interaksi simbolik. Simbol-simbol yang telah dibentuk langsung digunakan pada saat itu juga. Ega dan Ririn langsung menggunakan simbol yang telah dibentuk untuk proses penggunaan simbol dalam proses interaksi simbolik.

Proses Interaksi pada Tataran Mind, Self dan Society pada Tahap Pembentukan dan Penggunaan Simbol

Ketiga tataran pembentukan simbol (mind, self dan society) serta keempat tahap pembentukan dan penggunaan simbol (dorongan, persepsi, manipulasi dan konsumsi) bukan merupakan tahapan yang terpisah. Tahap dorongan, persepsi, manipulasi dan konsumsi melibatkan proses di tataran mind, self dan society. Pada proses interaksi simbolik antara Ibu Tina, Ega dan Ririn, berlangsung hampir tidak dapat dipisahkan satu sama lain. Hubungan dikaji melalui kasus pemberian pujian. 
Tabel 1. Matrik Hubungan antara Tataran Pembentukan

Simbol dan Tahapan Penggunaan Simbol

\begin{tabular}{|c|c|c|c|c|}
\hline & Dorongan & Persepsi & Manipulasi & Konsumsi \\
\hline Mind & $\begin{array}{l}\text { Menganggap } \\
\text { pujian itu } \\
\text { penting }\end{array}$ & $\begin{array}{l}\text { Memikirkan bentuk } \\
\text { pujian yang tepat }\end{array}$ & $\begin{array}{l}\text { Memikirkan cara } \\
\text { memberikan } \\
\text { pujian dan beraksi } \\
\text { terhadap cara } \\
\text { yang dianggap } \\
\text { berhasil atau } \\
\text { dianggap tidak } \\
\text { berhasil }\end{array}$ & $\begin{array}{l}\text { Memberikan } \\
\text { pujian }\end{array}$ \\
\hline Self & $\begin{array}{l}\text { Mengkonstruk- } \\
\text { sikan konsep } \\
\text { pujian }\end{array}$ & $\begin{array}{l}\text { Memahami makna } \\
\text { pujian bagi dirinya } \\
\text { dan orang lain } \\
\text { dalam konteks yang } \\
\text { berbeda sesuai } \\
\text { dengan konsep diri } \\
\text { yang terbangun }\end{array}$ & $\begin{array}{l}\text { Memilih cara-cara } \\
\text { melakukan pujian } \\
\text { atau memilih } \\
\text { reaksi terhadap } \\
\text { pujian }\end{array}$ & $\begin{array}{l}\text { Memuji atau } \\
\text { merespon pujian } \\
\text { sesuai dengan } \\
\text { makna pujian } \\
\text { yang dipahami } \\
\text { oleh konsep diri }\end{array}$ \\
\hline \begin{tabular}{|l|} 
Society \\
\end{tabular} & $\begin{array}{l}\text { Memilah } \\
\text { stimulus melalui } \\
\text { simbol pujian } \\
\text { sesuai dengan } \\
\text { latar belakang } \\
\text { sosial budaya }\end{array}$ & $\begin{array}{l}\text { Mempersepsikan } \\
\text { simbol pujian sesuai } \\
\text { dengan } \\
\text { kemampuannya } \\
\text { mempersepsikan } \\
\text { latar belakang sosial } \\
\text { budaya dengan } \\
\text { kondisi yang } \\
\text { dihadapi }\end{array}$ & 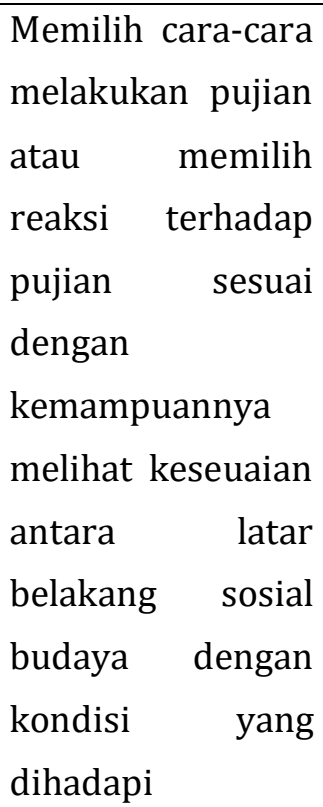 & $\begin{array}{l}\text { Memuji atau } \\
\text { merespon pujian } \\
\text { sesuai dengan } \\
\text { kemampuannya } \\
\text { melihat } \\
\text { keseuaian } \\
\text { antara latar } \\
\text { belakang sosial } \\
\text { budaya dengan } \\
\text { kondisi yang } \\
\text { dihadapi }\end{array}$ \\
\hline
\end{tabular}

Matrik di atas menunjukkan bagaimana proses simbol pujian dibentuk dan digunakan pada tataran mind, self dan society. Guru di tataran mind menganggap pujian penting diberikan untuk Ega dan
Ririn. Ini mendorong Ibu Tina untuk mempersepsikan bentuk pujian yang tepat kemudian memikirkan cara memberikan pujian dan beraksi terhadap cara yang dianggap berhasil atau dianggap tidak 
berhasil sampai pada akhirnya memberikan pujian dengan cara yang dianggap tepat oleh Ibu Tina. Cara yang tepat tersebut dipilih oleh Ibu Tina berdasarkan interaksi dengan Ega dan Ririn. Proses di tataran mind Ibu Tina tidak terlapas dari self. Konsep diri dan motif mengajar menjadi bagian penting yang mempengaruhi proses reaksi terhadap dorongan, persepsi, manipulasi dan penggunaan simbol pujian. Pada tataran society, Ibu Tina memilih cara memuji yang berbeda untuk Ega dan Ririn sesuai dengan latar belakang sosial budaya untuk Ririn. Ini karena Ega memiliki konsep diri yang lebih terbuka dan memiliki
Ega dan Ririn sesuai dengan latar belakang sosial budaya Ibu Tina sendiri.

Dari sisi Ega dan Ririn, perbedaan antara Ega dan Ririn menunjukkan perbedaan proses pembentukan dan penggunaan simbol di tataran mind, self dan society Ega dan Ririn. Ega lebih terbuka secara society sehingga proses di tataran mind dan self Ega lebih terbuka dibandingkan dengan Ririn. Ega lebih mampu mengartikan pujian Ibu Tina dan mentransformasi pujian Ibu Tina tidak hanya untuk diri sendiri namun juga

latar belakang sosial budaya yang lebih terbuka dibandingkan dengan Ririn.

\section{KESIMPULAN DAN IMPLIKASI}

\section{KESIMPULAN}

Penggunaan Simbol pada proses interaksi simbolik siswa tunagrahita dan guru mengkaji proses pembentukan dan penggunaan simbol di tatara mind, self dan society dalam interaksi Ibu Tina, Ega dan Ririn yang menunjukkan tataran mind, self dan society memiliki peran penting dalam proses interaksi simbolik. Proses interaksi simbolik di tataran mind membantu anakanak tunagrahita dan guru dalam menyamakan merespon atau membangun dorongan, mempersepsi simbol, menyamakan makna atas simbol sehingga terjadi kesepakatan atas simbol yang digunakan. Proses interaksi simbolik di tataran self memberikan pengaruh dalam bagaimana anak-anak tunagrahita dan guru untuk bertindak, berkembang serta memahami kelebihan dan kekurangan yang dimiliki diri sendiri dan orang lain sehingga dapat memilih dan menggunakan simbolsimbol yang tepat untuk orang yang tepat. Proses interaksi simbolik di tataran society menunjukkan level yang berbeda sesuai dengan latar belakang sosial dan budaya dari siswa. Kesepakatan yang dibangun melalui interaksi simbolik antara guru dengan siswa membantu siswa mengerti dan paham struktur sosial di sekolah maupun di rumah, sehingga mereka dapat membendakan bagaimana mereka bertindak dan berperilaku agar sesuai dengan individu lain. 


\section{IMPLIKASI}

Secara teoritis, Mead (dalam Elbadiansyah: 2014) menjelaskan kajian mengenai penggunaan simbol pada proses interaksi simbolik di tataran mind, self dan society dapat membantu memahami dan mencapai suatu pemaknaan. Sesuai dengan proses komunikasi antara siswa berkebutuhan tunagrahita dengan guru dalam memahami satu sama lain. Proses ini berbeda dengan proses antara manusia yang tidak memiliki keterbatasan karena terdapat perbedaan kemampuan pembentukan dan penggunaan pesan pada siswa tunagrahita.

Secara praktis, kasus interaksi simbolik antara Ibu Tina, Ega dan Ririn menunjukkan diperlukannya konsep diri guru yang tegas dan jelas agar mau dan mampu mengartikan kemampuan siswa tunagrahita dalam berinteraksi. Personalisasi di tataran self Ibu Tina dan self Ega dan Ririn merupakan faktor penentu keberhasilan komunikasi. Hal Ini menujukkan pentingnya kemampuan guru dalam memahami setiap proses yang mempengaruhi pembentukan dan penggunaan simbol pada diri siswa.

\section{DAFTAR PUSTAKA}

\section{Buku}

Atmaja, Jati Rinakri. 2018. Pendidikan dan Bimbingan Anak Berkebutuhan Khusus. Bandung (ID): PT Remaja Rosdakarya..

Creswell, J. W. 2013. Qualitative Inqury \& Research Design : Choosing Among Five Approaches (3rd ed.) London (UK): Thousand Oaks, CA: SAGE.

Elbadiansyah, Umiarso. 2014. Interaksionisme Simbolik dari Era Klasik hingga Modern. Jakarta (ID): PT Raja Grafindo Persada.

George Ritzer, Douglas J. Goodman. 2010. Teori Sosiologi Modern. Jakarta (ID): Kencana.

Moleong, L.J. 2016. Metodelogi Penelitian Kualitatif Edisi Revisi. Bandung (ID):.PT. Remaja Rodsakarya.

Nazir. 2014. Metode Penelitian. Bogor (ID):.Penerbit Ghalia Indonesia.

Sugiyono. 2016. Metode Penelitian Kuantitatif, Kualitatif, $R \& D$. Bandung (ID): Alfabeta.

\section{Laporan Wawancara}

Tina Rostina S.Pd, Guru Sekolah Luar Biasa, 6-12 Desember 2019

Ega, Siswa Tunagrahita, 6-12 Desember 2019

Ririn, Siswi Tunagrahita, 6-12 Desember 2019

Fajar, Teman terdekat Ega dan Ririn, 12 Desember 2019 